\title{
BAY-BREASTED WARBLER NESTING IN SASKATCHEWAN
}

M. ROSS LEIN, Dept. of Biology, University of Calgary, Calgary, Alberta, T2N $1 \mathrm{~N} 4$.

Houston et al have noted the lack of adequate documentation of nesting for a variety of birds that are regular summer residents of Saskatchewan. ${ }^{2}$ The present note provides documentation for one such species, the Baybreasted Warbler.

I spent part of the summer of 1969 at the field station of the Department of Biology, University of Saskatchewan, at Emma Lake, Saskatchewan. Bay-breasted Warblers were moderately abundant in mixed woods in the region and two nests were found.

On 8 June a female Bay-breasted Warbler was seen carrying nesting material near the southeast corner of Fairy Island. An incomplete nest was located near the top of an 8-m white spruce (Picea glauca), on the tip of a branch about $1 \mathrm{~m}$ from the trunk. The female was incubating on 12 June, and on 13 June the nest contained four eggs. The nest was a relatively flimsy structure of twigs and grass. It was empty when visited on 22 June, presumably as a result of predation.

A second nest was found on 13 June in mixed woods near the $U$. of $S$. Art School. The female was carrying material to a nest located at a height of $8 \mathrm{~m}$ in a 13-m white spruce. On 22 June this nest contained 3 eggs and the female was still incubating when the nest was last visited on 26 June.

The relatively distinctive plumage of the female Bay-breasted Warbler leaves no doubt about the identity of the birds at either nest. Male Baybreasted Warblers were also seen feeding the incubating females on several occasions at both nests.

There are breeding season records of singing males ${ }^{13456}$ or fledglings ${ }^{1}$ of this species from a number of locations in the boreal forest region of Saskatchewan. It seems probable that the Bay-breasted Warbler breeds throughout this region.

'GODFREY, W. D. 1950. Birds of the Cypress Hills and Flotten Lake regions, Saskatchewan. Nat. Mus. Canada Bull. 120. 96 pp.

${ }^{2}$ HOUSTON, C. S., M. I. HOUSTON and J. B. GOLLOP. 1980. Breeding birds in Saskatchewan without documented nests. Blue Jay 38:87-95.

${ }^{3}$ HOUSTON, C. S. and M. G. STREET. 1959. The birds of the Saskatchewan River, Carlton to Cumberland. Spec. Publ. Sask. Nat. Hist. Soc. No. 2. 205 pp.

${ }^{4}$ NERO, R. W. 1967. The birds of northeastern Saskatchewan. Spec. Publ. Sask. Nat. Hist. Soc. No. 6. 96 pp.

${ }^{5}$ RANDALL, T. E. 1962. Birds of the Kazan Lake region, Saskatchewan. Blue Jay 20:60-72.

${ }^{6}$ SOPER, J. D. 1952. The birds of Prince Albert National Park, Saskatchewan. Can. Wildl. Serv., Wildl. Manage. Bull., Ser. 2, No. 4.83 pp. 